\section{A Versatile Heat Pump Seed Dryer}

Vincent A. Fritz ${ }^{1}$

\author{
Southern Experiment Station, University of Minnesota, Waseca, \\ MN 56093
}

\author{
Harold A. Cloud ${ }^{2}$ \\ Department of Agricultural Enginneering, University of Minnesota, St. \\ Paul, MN 55108
}

\author{
Robert F. Deef ${ }^{3}$ \\ Southern Experiment Station, University of Minnesota, Waseca, \\ MN 56093
}

\author{
Alicia M. Borowski ${ }^{4}$ \\ Department of Horticultural Science, University of Minnesota, St. Paul, \\ MN 55108 \\ Additional index words. $\quad$ sweet corn, Zea mays var. rugosa
}

\begin{abstract}
An experimental research seed dryer based on the heat pump principle was built to dry sweet corn (Zea mays var. rugosa L.) seed on husked ears. The dryer is not susceptible to environmentally induced drying rate fluctuations that are common with a conventional open-system forced-air oven. The dryer operates as a closed system and, as a result, provides a more constant drying environment. The ability to control air flow, temperature, and humidity makes the dryer a valuable tool for seed production research.
\end{abstract}

Environmental conditions during late summer and early-fall in southern-Minnesota create a significant barrier to effectively using conventional drying methods for sweet corn seed production. We have observed that, in favorable environments ( $\leq 30 \% \mathrm{RH})$, an opensystem, gas-fired, forced-air dryer with internal air temperatures of 32 to $35 \mathrm{C}$ would be adequate. However, during periods of high humidity (dewpoint 15 to $20 \mathrm{C}$ ), drying rate fluctuates widely due to the high atmospheric vapor pressure at the seed surface. This can result in a moisture gain rather than a loss. If air temperature is increased to regain an effective drying rate, seed germination subsequently declines (Navratil and Burris, 1982, 1984; Wellington and Bradnock, 1964). McRostie (1949) found that the damage to dent corn was amplified when the initial seed moisture content exceeded $50 \%$. Seyedin et al. (1984) found that as drying temperature increased from 35 to $50 \mathrm{C}$, electrical conductivity of leachate increased, suggesting membrane damage. These limitations in seed drying prompted the development of a closed-system dryer to provide more control over the drying process for research purposes.

Therefore, we constructed a dryer (Fig. 1, Table 1) independent of the external envi-

Received for publication 10 July 1989. Minnesota Agr. Expt. Sta. Journal Series no. 17,232. The cost of publishing this paper was defrayed in part by the payment of page charges. Under postal regulations, this paper therefore must be hereby marked advertisement solely to indicate this fact.

'Assistant Professor.

${ }^{2}$ Professor Emeritus.

${ }^{3}$ Maintenance Supervisor.

${ }^{4}$ Graduate Research Assistant. ronment (closed system), one that operates on the heat pump principle (Flikke et al., 1957). The system (Fig. 1) uses a 5.4-kPa compressor unit, a belt-drive fan (Fig. 1, a), and an evaporator coil located within the air flow duct at the mouth of the dryer exhaus (Fig. 1, b). High-moisture air at $\approx 28 \mathrm{C}$, passes through the evaporator coil and is cooled to $12 \mathrm{C}$. This procedure effectively removes excess moisture through condensation, with the condensate being discharged from the system. The relatively cool, dry air then passes through two reheat coils (Fig. 1, c and d) that heat the air to $35 \mathrm{C}$ before it enters the dryer chamber with a relative humidity of $\approx 20 \%$ to $25 \%$. To maintain a constant air temperature, a bypass valve (Fig. 1, e) was installed between the two reheat coils. The valve is thermostatically controlled and will divert a percentage of the total air to bypass the second reheat coil if air temperature begins to exceed the target temperature. The excess heat is ejected through the external condenser (part of the compressor unit) to help maintain the target temperature if air is bypassed around the second reheat coil. The diverted air is then remixed-with the air that passed through the second reheat coil before entering the main dryer chamber $(2 \times 2 \times$ $1.25 \mathrm{~m})$ through a plenum $(2 \times 0.30 \times 1.25$ $\mathrm{m})$ below the three subchambers (Fig. 2). The main dryer chamber and subchambers are constructed of 1.9-cm thick plywood. Each subchamber is comprised of 10 drawers (61 $\times 61 \times 18 \mathrm{~cm})$ with wire screen $(1.3-\mathrm{cm}$ mesh) bottoms for holding ear corn in either single or multiple layers. Manually controlled dampers can be adjusted just below each subchamber if only one or two subchambers are needed for drying. This arrangement increases the flexibility of the dryer. Thermometer ports were installed in the main dryer chamber at strategic locations to closely monitor air temperature (Fig. 1, f). Seed drying time ranged by a factor of

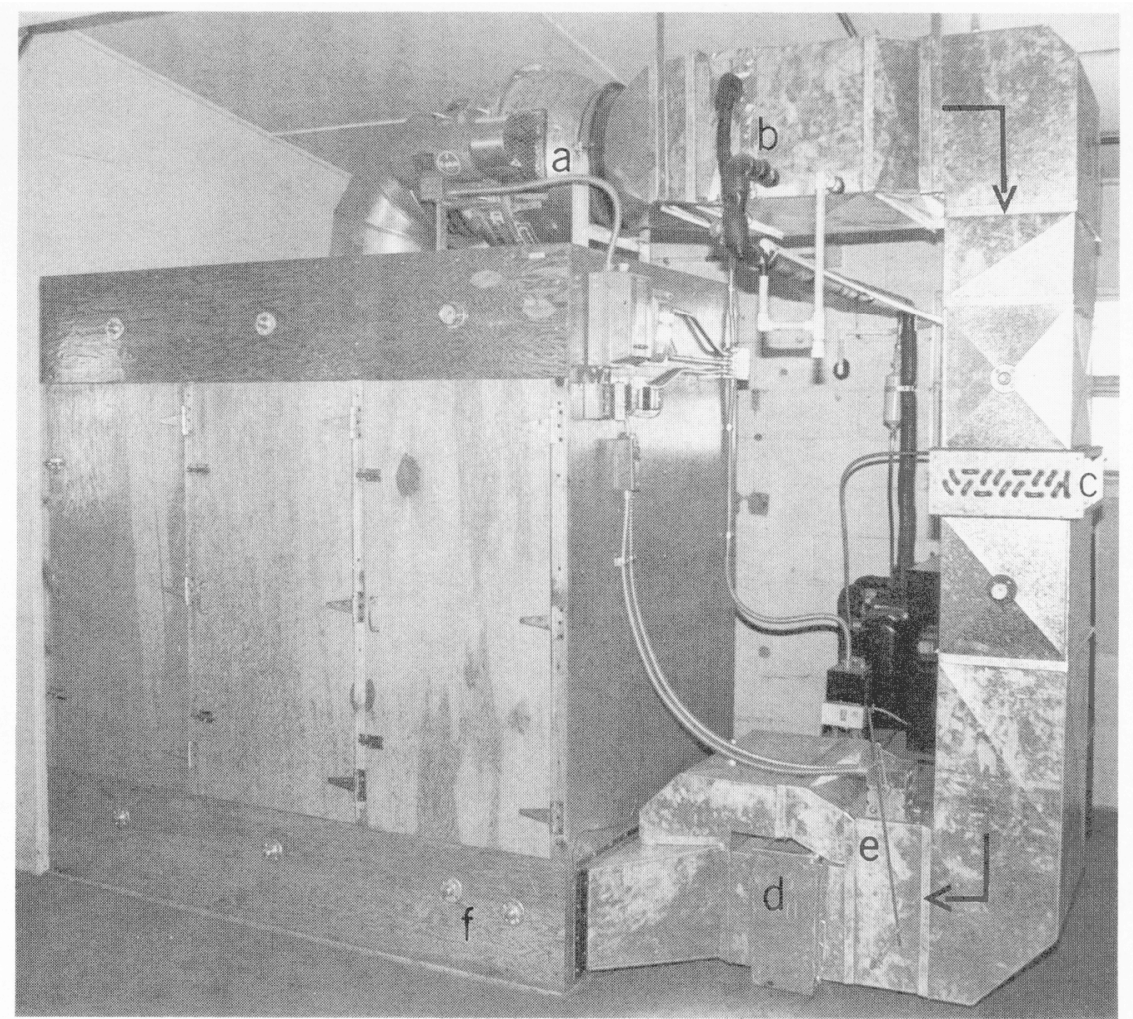

Fig. 1. Frontal view of the heat pump seed dryer with arrows indicating direction of air flow; (a) fan, (b) evaporator coil, (c, d) reheat coils, (e) bypass valve, and (f) thermometer ports. 
Table 1. Specifications of various components used in the seed dryer.

\begin{tabular}{|c|c|c|c|}
\hline Specification & \multicolumn{2}{|c|}{ Fan } & Compressor unit \\
\hline Type & \multicolumn{2}{|c|}{ In-line vane, belt drive } & $240 \mathrm{~V}, 3$ phase \\
\hline Model & \multicolumn{2}{|c|}{$16 \mathrm{CVB}$} & F 3AD-0401 \\
\hline Kilopascals & \multirow{2}{*}{\multicolumn{2}{|c|}{$\begin{array}{l}1.3 \\
31-51\end{array}$}} & \multirow{2}{*}{5.4} \\
\hline Air flow $\left(\mathrm{m}^{3} / \mathrm{sec}\right)$ & & & \\
\hline \multirow[t]{2}{*}{ Manufacturer: } & \multicolumn{2}{|c|}{$\begin{array}{l}2015 \text { E. Dale St., } \\
\text { Springfield, MO } \\
65803\end{array}$} & $\begin{array}{l}\text { Total Refrigeration } \\
\text { Systems, Inc., } \\
1100 \text { N. Concord St., } \\
\text { South St. Paul, MN 55074 }\end{array}$ \\
\hline & \multicolumn{2}{|c|}{ Evaporator coil } & Duct bypass damper \\
\hline Tube diameter $(\mathrm{cm})$ & 1.3 & 1.3 & $\ldots$ \\
\hline Fin type & Corrugated & Corrugated & $\ldots$ \\
\hline Fin material & Aluminum & Aluminum & $\ldots$ \\
\hline Fins/cm & 3.1 & 3.9 & $\ldots$ \\
\hline \multicolumn{4}{|l|}{$\begin{array}{l}\text { Dry bulb air } \\
\text { temperature }\left({ }^{\circ} \mathrm{C}\right)\end{array}$} \\
\hline Entering & 21 & $13(27)^{2}$ & $\ldots$ \\
\hline Leaving & 13 & $27(38)^{2}$ & $\ldots$ \\
\hline \multicolumn{4}{|l|}{ Refrigerant } \\
\hline temperature $\left({ }^{\circ} \mathrm{C}\right)$ & 5 & 43 & $\ldots$ \\
\hline Refrigerant type & $\mathrm{R}-22$ & $\mathrm{R}-22$ & $\ldots$ \\
\hline Face velocity $(\mathrm{m} / \mathrm{see})$ & 146 & 146 & $\ldots$ \\
\hline \multicolumn{4}{|l|}{ Required } \\
\hline capacity (J/hr) & $44 \times 10^{6}$ & $28.7 \times 10^{6}$ & $\ldots$ \\
\hline Air friction $(\mathrm{cm})$ & 2.0 & 0.5 & $\ldots$ \\
\hline Dimensions (cm) & \multicolumn{3}{|c|}{$\begin{array}{r}67.3 \times 38.1 \times 22.967 .3 \times 38.1 \times 16.561 .0 \times 47.7 \text { with } 30.5 \\
\text { face and } 15.2 \text { bypass }\end{array}$} \\
\hline Manufacturer: & \multicolumn{2}{|c|}{$\begin{array}{l}\text { Thermo-Dyne, Inc., } \\
1511 \text { Excelsior Ave.. } \\
\text { E. Hopkins, MN } 55343\end{array}$} & $\begin{array}{l}\text { Dowco Corp., } \\
\text { 3156 Irving Blvd., } \\
\text { P.O. Box 47604, } \\
\text { Dallas, TX } 75247\end{array}$ \\
\hline
\end{tabular}

'Air temperatures entering and leaving the second reheat coil if the bypass damper is closed.

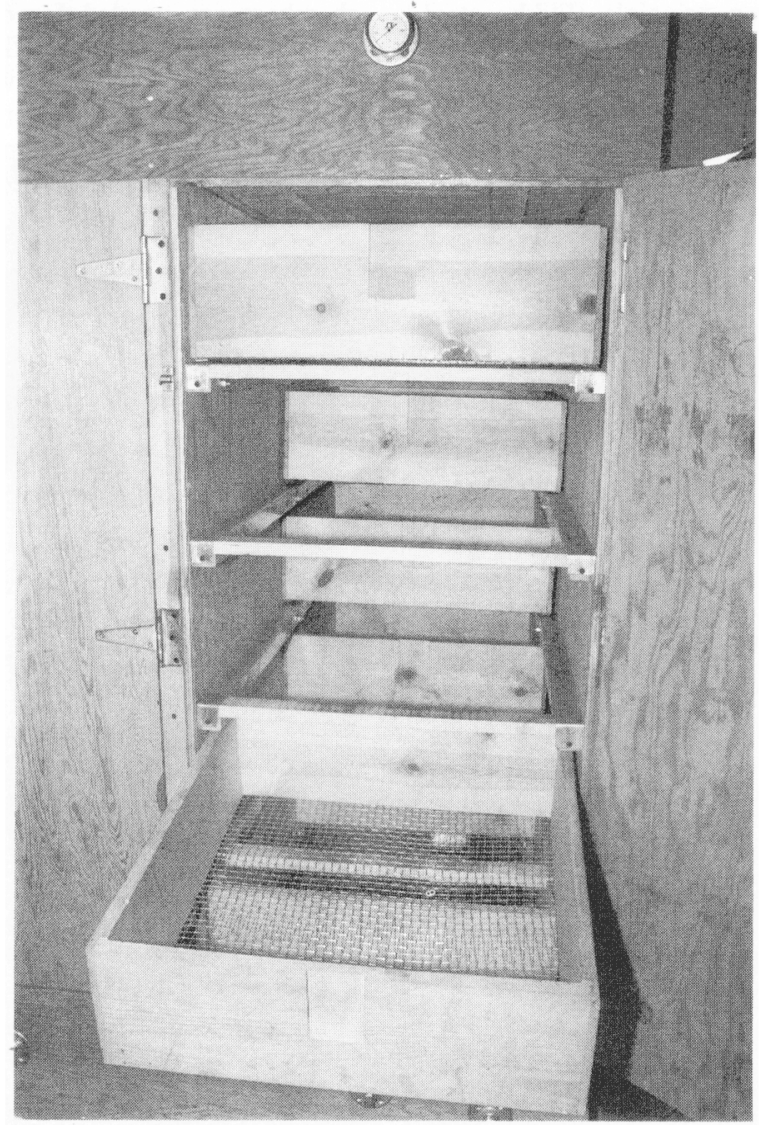

Fig. 2. Internal view of one of three subchambers with 10 seed drawers.
Table 2. Drying rate of 'Florida Staysweet' sweet corn seed with air at $27 \mathrm{C}$ entering the dryer.

\begin{tabular}{|c|c|}
\hline $\begin{array}{c}\text { Seed moisture } \\
\text { at harvest } \\
(\%)\end{array}$ & $\begin{array}{c}\text { Drying time } \\
\text { required to reach } \\
10 \% \text { seed moisture } \\
(\mathrm{hr})\end{array}$ \\
\hline 70 & 188 \\
\hline 60 & 114 \\
\hline 50 & 98 \\
\hline 40 & 64 \\
\hline 30 & 20 \\
\hline
\end{tabular}

$\approx 9$ for a moisture content that ranged by a factor of 2.3 (Table 2).

The dryer has the capability to modify air flow by adjusting the diameter of the fan intake, temperature, and humidity, which makes it a valuable research tool in studying the effects of gradually declining seed moisture on embryo integrity, seed germinability, and seedling vigor in small seed lots of sweet corn.

The necessary materials for construction cost about \$6100, not including labor. The main dryer chamber can be easily constructed. However, installation of the fan, compressor unit, reheat and evaporator coils, and the bypass damper- should be supervised by an electrician and refrigeration specialist.

\section{Literature Cited}

Flikke, A. M., H.A. Cloud, and A. Hustrolid. 1957. Grain drying by heat pump. J. Amer. Soc. Agr. Eng. 38(8):592-597.

McRostie, G.P. 1949. Some factors influencing the artificial drying of mature grain corn. Agron. J. 41:425-429.

Navratil, R.J. and J.S. Burris. 1982. Small-scale dryer design. Agron. J. 74:159-161.

Navratil, R.J. and J.S. Burris. 1984. The effect of drying temperature on corn seed quality. Can. J. Plant Sci. 64:487-496.

Seyedin, N., J.S. Burris, and T.E. Flynn. 1984. Physiological studies on the effects of drying temperatures on corn seed quality. Can. J. Plant Sci. 64:497-504.

Wellington, P.S. and W.T. Bradnock. 1964. Studies on the germination of cereals, 6 . The effect of heat during artificial drying on germination and seedling development in barley. J. Natl. Inst. Agr. Bet. 10:129-143. 